\title{
Aortic cusp extension valvuloplasty: repair with an extracellular patch
}

\author{
Roman Przybylski ${ }^{1}$, Szymon Pawlak ${ }^{1}$, Joanna Śliwka ${ }^{1}$, Maciej Urlik ${ }^{1}$, Marcin Maruszewski ${ }^{1}$, \\ Tomasz Kukulski ${ }^{2}$, Jerzy Nożyński ${ }^{3}$, Marian Zembala ${ }^{1}$ \\ ${ }^{1}$ Department of Cardiac Surgery and Transplantation, Medical University of Silesia in Katowice, \\ School of Medicine with Division of Dentistry in Zabrze, Silesian Center for Heart Diseases, Poland \\ ${ }^{2} 1^{\text {st }}$ Department of Cardiology, Medical University of Silesia in Katowice, School of Medicine \\ with Division of Dentistry in Zabrze, Silesian Center for Heart Diseases, Poland \\ ${ }^{3}$ Histopathology lab, Silesian Center for Heart Diseases, Poland \\ Kardiochirurgia i Torakochirurgia Polska 2015; 12 (4): 314-317
}

\begin{abstract}
Introduction: The proportion of valve repair procedures is increasing in experienced centers. The aim of the study was to assess the clinical and echocardiographic outcomes after aortic valve reconstruction with a novel surgical technique.

Material and methods: The study group consisted of 30 patients (23 male and 7 female) at a mean age of $35 \pm 14$ years. In patients with aortic root aneurysm the reimplantation or Florida sleeve technique was used. A sub-commissural annuloplasty, plication of the free edge of the cusp, shaving, and commissurotomy were performed. At this stage of surgery aortic repair was then attempted by cusp extension. Since 2013 the strips have been tailored from extracellular matrix.

Results: The mean aortic cross-clamp time was $90 \pm 32 \mathrm{~min}$. The mean cardiopulmonary bypass time was $126 \pm 38 \mathrm{~min}$. There was no in-hospital death. Re-exploration for bleeding was required in 1 patient. During follow-up, 1 patient needed reoperation at 1 year due to endocarditis. All patients remained alive in New York Heart Association (NYHA) functional class I. The echocardiographic findings remained unchanged in all cases during follow-up.

Conclusions: Our modification of aortic valve repair results in a good outcome.
\end{abstract}

Key words: cusp extension, aortic valve repair.

\section{Introduction}

Repair of the aortic valve has received noticeably less attention than repair of the mitral or tricuspid valves. Techniques of valve repair have been published for over 50 years [1]. Aortic valve repair techniques have drawn attention since Carpentier reported a large number of repairs in 1983 [2]. The functional structure and redundancy of the mitral and tricuspid valves may be more amenable to remodeling

\section{Streszczenie}

Wstęp: W doświadczonych ośrodkach zwiększa się liczba wykonywanych plastyk zastawki aortalnej. Celem pracy była ocena wyników klinicznych i echokardiograficznych po rekonstrukcji zastawki aortalnej z użyciem nowej techniki operacyjnej.

Materiał i metody: Badaniami objęto 30 chorych (23 mężczyzn i 7 kobiet) w średnim wieku $35 \pm 14$ lat. U chorych z tętniakiem opuszki aorty wykonywano reimplantację albo egzoprotetyczną naprawę. Następnie wykonywano podspoidłową plastykę, plikację płatka, ścięcie zwłókniałego wolnego brzegu płatka, komisurotomię. Powiększano płatki zastawki łatkami. Od 2013 r. łatki były wycinane z macierzy zewnątrzkomórkowej. Wyniki: Średni czas zakleszczenia aorty wyniósł $90 \pm 32$ minuty. Średni czas krążenia pozaustrojowego wyniósł $126 \pm 38$ minut. Nie było zgonów szpitalnych. Reoperacja z powodu zwiększonego drenażu była konieczna u 1 pacjenta. W dalszym przebiegu, po roku, jednego pacjenta reoperowano z powodu zapalenia wsierdzia. Wszyscy pacjenci żyją i pozostają w klasie NYHA I. Wyniki badań echokardiograficznych potwierdzają dobrą funkcję naprawionych zastawek aortalnych.

Wnioski: Wprowadzona nowa technika operacyjna cechuje się dobrym wynikiem krótkoterminowym.

Słowa kluczowe: powiększenie płatków, naprawa zastawki aortalnej.

techniques. Most surgeons treat every aortic valve pathology with a prosthetic replacement. Although this treatment strategy is justified by excellent long-term results, complications such as thromboembolism, endocarditis, and need for long-term anticoagulation [3] have become the driving force in the quest for a surgical procedure that will save the native aortic valve. Therefore the proportion of valve repair procedures is increasing in experienced centers. 
The aim of this study was to assess the clinical and echocardiographic outcomes after aortic valve reconstruction with a novel surgical technique consisting of:

- functional classification and correlation with the surgical procedure as proposed by El Khoury,

- cusp extension,

- small intestinal submucosa-extracellular matrix (SIS-ECM) patch (CorMatrix Cardiovascular, Inc, Alpharetta, GA).

\section{Material and methods \\ Patients}

Between May 2008 and October 2015, 30 patients underwent aortic valve repair with cusp extension including 5 patients who underwent an aortic valve-sparing procedure with a David or Florida sleeve. All patients were diagnosed with isolated severe aortic valve regurgitation. The group consisted of 23 men and 7 women with a median age of 35 years (range 9 to 60 years). Preoperative patient characteristics are shown in Table I. Preoperative echocardiographic assessment is shown in Table II.

\section{Surgical technique}

All cases were approached via median sternotomy. Following cannulation of the ascending aorta and the right atrium mild hypothermic $\left(32^{\circ} \mathrm{C}\right)$ cardiopulmonary bypass was commenced. Myocardial protection was achieved with antegrade cold blood cardioplegia. In patients with aortic root aneurysm (El Khoury functional classification Type Ib [4]) the reimplantation or Florida sleeve technique was used. In all cases of reimplantation, sutures without Teflon felt on the annulus and cusp extension instead of a running Gore-Tex suture were applied according to the Jeanmart method [5]. Depending on the extent of the root aneurysm in cases where symmetrical widening was observed, the Florida sleeve method was used [6]. The technique [7] entails reimplantation of the entire aortic root into a Dacron graft. The graft must be of an appropriate size to obtain adequate aortic valve competence. To assess the size of the prosthesis needed, the commissural stitches are pulled up and then brought inward until a good line of coaptation is obtained. The space between the three commissures is approximated by calibrators of standard diameter. Finally, surgical cusp extension is performed.

In 11 patients with El Khoury type Ic lesion, a sub-commissural annuloplasty was performed as the most appropriate surgical procedure. Type II cusp prolapse was treated by plication of the free edge of the cusp in 25 patients. In 10 cases of type III the lesions were excised by shaving the leaflet. Nodular calcifications were enucleated (2 patients).
Commissural fusion was freed by blade commissurotomy (5 patients). At this stage of surgery aortic repair was then attempted by cusp extension [8]. An autologous pericardial patch was harvested and stabilized with glutaraldehyde (5 patients). Three rectangular strips were tailored from the patch. The height of the strips was fixed at $8 \mathrm{~mm}$. Each strip was then sutured to the corresponding free edge of the aortic cusp using 7-0 Gore-Tex sutures. The neocommissures were then elevated to the height of the strip $(8 \mathrm{~mm})$. The commissural coaptation was secured with 4-0 Prolene. Since 2013 (17 patients) the strips have been tailored from an extracellular matrix (SIS-ECM) patch (CorMatrix Cardiovascular, Inc, Alpharetta, GA).

After weaning from cardiopulmonary bypass, a complete transesophageal echocardiogram was performed to evaluate the valve function. The primary goal was to achieve the height of the line of coaptation of the leaflets well above the plane of the aortic annulus.

\section{Statistical analysis}

Data are expressed as means \pm SEM. Analysis of variance ranks for dependent samples (Friedman ANOVA) was performed using Statistica $12 \mathrm{PL}$.

\section{Results}

No operations required conversion to prosthetic valve replacement. The mean aortic cross-clamp time was $90 \pm$ $32 \mathrm{~min}$. The mean cardiopulmonary bypass time was 126 $\pm 38 \mathrm{~min}$. There was no in-hospital death. Re-exploration for bleeding was required in 1 patient. The mean length of stay was 6 days.

Two patients with aortic root aneurysm required reimplantation of the aortic valve. Three patients with dilata-

Tab. I. Preoperative patient characteristics

\begin{tabular}{lc} 
Variable & Data \\
Age in years, median (range) & $35(9-60)$ \\
\hline Male/female & $23 / 7$ \\
\hline Functional class & \\
\hline NYHA II & 11 \\
\hline NYHA III & 8 \\
\hline Previous cardiac surgery & 1 \\
\hline Concomitant diseases & 14 \\
\hline Hypertension & 1 \\
\hline Previous neurologic events
\end{tabular}

Tab. II. Echocardiographic studies

\begin{tabular}{lccc} 
Variable & Preoperative & Postoperative & Follow-up \\
Mean Al (vena contracta) & $8 \pm 1.15$ & $0.9 \pm 1$ & $1.25 \pm 2$ \\
\hline Mean AVG (mmHg) & $8 \pm 4$ & $10.5 \pm 7.5$ & $9.25 \pm 5.6$ \\
\hline
\end{tabular}

Al - aortic insufficiency, AVG - aortic valve gradient 
tion of the aortic root were treated using the Florida sleeve technique.

Postoperative echocardiography at discharge showed no or trivial insufficiency in all patients. The opening and closing movements of the aortic cusps were also favorable in all patients, regardless of the surgical method used for root repair.

During follow-up, which was completed for all patients and averaged $40 \pm 30$ (range: 2-89) months, 1 patient needed reoperation at 1 year due to endocarditis. All patients remained alive in NYHA functional class I. No embolic event was recorded in the study group, where only a small dose (75 mg) of daily aspirin was introduced as prevention of thromboembolism. The echocardiographic findings remained unchanged in all cases during follow-up.

\section{Discussion}

The reimplantation technique provided more stable valve function than remodeling during the first 10 years of follow-up in patients with aortic root aneurysm [9].

In a recent report by David on experience with reimplantation of the aortic valve in 296 patients, only 3 patients required reoperation on the aortic valve and 11 developed moderate or severe aortic insufficiency. In that series, the freedom from reoperation at 15 years was $98 \%$ and the freedom from moderate or severe aortic insufficiency was $89 \%$. Marfan syndrome was protective against the development of late aortic insufficiency [10].

Although remodeling of the aortic root is physiologically superior to reimplantation of the aortic valve, long-term follow-up suggests that the latter is associated with lower risk of developing aortic insufficiency. Failure of remodeling of the aortic root is often due to dilatation of the aortic annulus.

Understanding the processes underlying insufficiency progression in patients with ascending aortic pathologies,

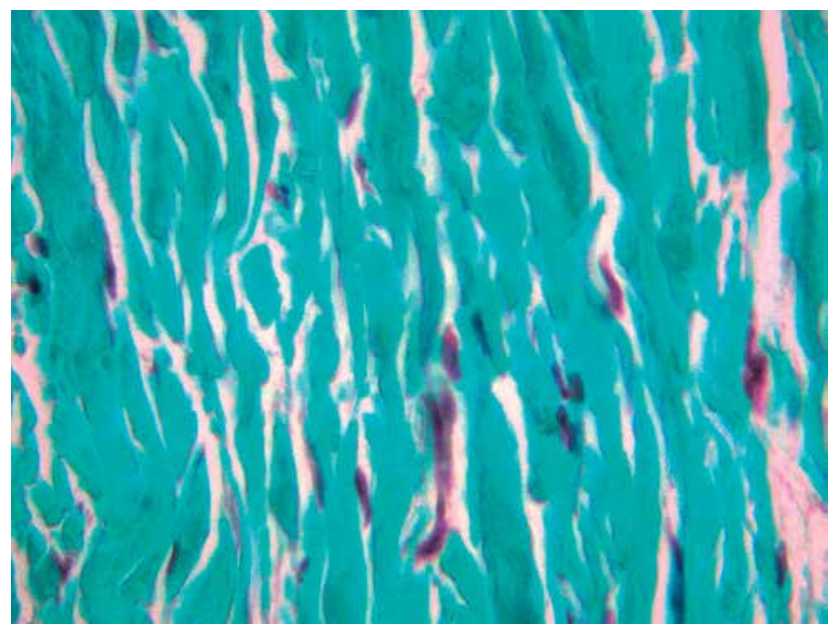

Fig. 1. Small intestinal submucosa-extracellular matrix (SIS-ECM) patch (CorMatrix Cardiovascular, Inc, Alpharetta, GA) 8 months after Vosschulte operation, at 1 month of age. Green collagen fibers without any degenerative process are arranged closely and repopulated with some cells. Trichrome staining. Magnification 400x as well as the aortic root structure and function, has become the basis for the development and implementation of extravalvular exoprosthetic repair of the aortic root (the Florida sleeve procedure), a new approach to valve-sparing surgery for the aortic root. The Florida sleeve technique allows aortic root reconstruction to be combined with aortic valve annuloplasty. In addition, the use of this procedure makes it possible to strengthen the aortic root and sinuses of Valsalva, and to repair the sinotubular junction, and to preserve the stereometry of aortic root components [6]. It also eliminates the need for reimplantation of coronary arteries, cutting out the sinuses, and fixing the commissures, which in turn reduces the risk of bleeding and potential torsion of coronary arteries during reimplantation. Therefore, if aortic insufficiency is accompanied by an aneurysm of the aortic root, we would recommend reimplantation or the Florida sleeve technique. Regardless of the technique used to repair the dilated aortic root, the cusps must coapt above the level of the nadir of the aortic annulus and the coaptation length must be at least $4 \mathrm{~mm}$ in the central part of the valve [11]. Although the aortic valve closes at the end of systole mainly due to lowering of the axial pressure difference, also the pooling of blood into the aortic sinuses may be involved in the diastolic closing phase. The aortic valve is exposed to laminar shear stress on the ventricular side when the blood flows past the leaflets during systole, and to oscillatory shear stress on the aortic side when blood pools into the sinuses during diastole. The diastolic coronary flow partially induces laminar shear stress over the left and right cusps, whereas the flow over the non-coronary cusp may be solely oscillatory. Interestingly, an echocardiographic study identified the non-coronary cusp as firstly affected by thickening, suggesting that lower laminar shear stress, in the absence of diastolic coronary flow, may accelerate valvular thickening [12]. The axial pressure acts on the basis of the aortic cusp. A surgical procedure (according to the El Khoury method: a sub-commissural annuloplasty, plication of the free edge of the cusp, shaving the leaflet, enucleated nodular calcifications, and commissurotomy) may result in tightness of the aortic valve. Oscillatory shear stress mostly affects the native tissue.

In contrast to the leaflet edge extension, a patch enlargement of the cusp at its base is much easier [13] but exposes the pericardial patch to the impact of axial pressure. An increase in the coaptation area can also be achieved by leaflet extension, in which a pericardial strip is sewn to the free edge of the cusp. This makes the patch less influenced by compression forces. In aortic cusp retraction the lack of leaflet tissue requires a leaflet extension procedure in order to increase the area of leaflet coaptation. Using three rectangular strips, the height of which was fixed at $8 \mathrm{~mm}$, we have adopted a simplification of the initial technique described by Duran and associates [14]. This reproducible surgical procedure appears to be safe and has provided good initial results. The material of choice for extension is still debated: glutaraldehyde-stabilized autologous pericardium, extracellular matrix patch or some other material. Our previous experience with newborns operated on be- 
cause of hypoplastic left heart syndrome using an extracellular matrix (SIS-ECM) patch (CorMatrix Cardiovascular, Inc, Alpharetta, GA) (Fig. 1) has encouraged us to use this patch for the cusp extension procedure.

In a recent multicenter study [15] among 8 cases of aortic arch repair with the SIS-ECM scaffold, no case of restenosis or aneurysm had occurred in the aortic position at midterm follow-up. On the other hand, redo surgery consisted of valve replacement for failing aortic plasty in 5 out of 10 patients who had undergone leaflet extension repair with SIS-ECM. Extracellular matrix scaffolds consist of structural and functional molecules secreted by the resident cells of each tissue and organ from which they are prepared. When implanted in the host tissue, proteolytic degradation of the ECM scaffold by immunomodulatory pro-remodeling macrophages produces biochemical triggers that attract progenitor cells and, together with the surrounding biomechanical and fluid dynamic environment, induce progenitor cell proliferation and phenotypic maturation.

In less than four months after being sutured into pericardium this patch has transformed into pericardium itself [16], and used as tubular form sutured into tricuspid valve has formed into the valve tissue [17]. Provided the shaved aortic valve leaflets were fibrous, ECM-SIS patch attached might possibly form into keloid. Perhaps this factor plays an important role as compared to small forces acting to enlarge the leaflet coaptation. We speculate, that it is not the patch itself but the way it was applied, cusp extension or suturing into the leaflet, that may influence the long-term outcome. In a paper published by Padalino [15] all cases with leaflet augmentation presented with good functional outcome on echocardiographic assessment.

\section{Conclusions}

Our preliminary results showed that involving: aortic valve plasty according to the El Khoury functional classification, cusp extension with no tension, SIS-ECM results in a good outcome and suggest that this technique should be considered as a viable procedure for surgical aortic valve repair.

At the follow-up, patients who underwent aortic valve leaflet repair with leaflet augmentation presented with good functional outcome.

\section{Acknowledgement}

SUM statutory work No. KNW-1-157/P/0/2 “Zabiegi rekonstrukcyjne zastawki aortalnej z wykorzystaniem acelularnej łaty - wprowadzenie metody" [in Polish].

\section{Disclosure}

Authors report no conflict of interest.

\section{References}

1. Starr A, Menashe V, Dotter D. Surgical correction of aortic insufficiency associated with ventricular septal defect. Surg Gynecol Obstet 1960; 111: 71-76.

2. Carpentier A. Cardiac valve surgery - the "French correction". J Thorac Cardiovasc Surg 1983; 86: 323-337.

3. Carr J, Savage E. Aortic valve repair for aortic insufficiency in adults: a contemporary review and comparison with replacement techniques. Eur J Cardiothorac Surg 2004; 25: 6-15.

4. El Khoury G, Glineur D, Rubay J, Verhekst R, d'Acoz Y, Poncelet A, Astarci P, Noirhomme Ph, van Dyck M. Functional classification of aortic root/valve abnormalities and their correlation with etiologies and surgical procedures. Curr Opin Cardol 2005; 20: 115-121.

5. Jeanmart H, Kerchove L, Glineur D, Goffinet J, Rouguio I, Dyck M, Nirhomme P, El Khoury G. Aortic valve repair: the functional approach to leaflet prolapsed and valve-sparing surgery. Ann Thorac Surg 2007; 83: 746-751.

6. Chernyavskiy A, Alsov S, Khvan D, Sirota D. Pozazastawkowa egzoprotetyczna naprawa korzenia aorty: pierwsze doświadczenie. Kardiochir Torakochir Pol 2012; 9: 409-414.

7. Hess P, Klodell C, Beaver T, Martin T. The Florida sleeve: a new technique for aortic root remodeling with preservation of the aortic valve and sinuses. Ann Thorac Surg 2005; 80: 748-750.

8. Grinda J, Latremouille C, Berrebi A, Zegdi R, Chauvaud S, Carpentier A, Fabiani J, Deloche A. Aortic cusp extension valvuloplasty for rheumatic aortic valve disease: midterm results. Ann Thorac Surg 2002; 74: 438-443.

9. David T, Feindel C, Webb G, Colman J, Armstrong S, Maganti M. Long-term results of aortic valve-sparing operations for aortic root aneurysm. J Thorac Cardiovasc Surg 2006; 132: 347-354.

10. David TE, Armstrong S, Manlhiot C, McCrindle BW, Feindel CM. Long term results of aortic root repair using the reimplantation technique. J Thorac Cardiovasc Surg 2013; 145 (3 Suppl): 22-25.

11. Oka T, Okita Y, Matsumori M, Okada K, Minami H, Munakata H, Inoue T, Tanaka A, Sakamoto T, Omura A, Nomura T. Aortic regurgitation after valvesparing aortic root replacement: modes of failure. Ann Thorac Surg 2011; 92: 1639-1644.

12. Back M, Gasser T, Michel J, Caligiuri G. Biomechanical factors in the biology of aortic wall and aortic valve diseases. Cardiovasc Res 2013; 99: 232-241.

13. Urbanski P. Basal cusp enlargement for repair of aortic valve insufficiency. J Thorac Cardiovasc Surg 2010; 139: 98-102.

14. Duran C, Kumar N, Gometza B, Al-Halees Z. Indications and limitations of aortic valve reconstruction. Ann Thorac Surg 1991; 52: 447-454.

15. Padalino M, Quarti A, Angeli E, Frigo A, Vida V, Pozzi M, Gargiulo G, Stellin G. Early and mid-term clinical experience with extracellular matrix scaffold for congenital cardiac and vascular reconstructive surgery: a multicentric Italian study. Interact Cardiovasc Thorac Surg 2015; 21: 40-49.

16. Scholl F, Boucek M, Chan K, Valdez-Cruz L, Perryman R. Preliminary experience with cardiac reconstruction using decellularized porcine extracellular matrix scaffold: human application in congenital heart disease. World J Pediatr Congenit Heart Surg 2010; 1: 132-136.

17. Zafar F, Hinton R, Moore R, Baker S, Bryant R, Narmoneva D, Taylor M, Moraled $D$. Physiological growth, remodeling potential, and preserved function of a novel bioprosthetic tricuspid valve. J Am Coll Cardiol 2015; 66: 877-888. 